\title{
Research on the Evaluation Criteria for the Cultivation of Innovative and Entrepreneurial Talents in Colleges and Universities
}

\author{
Boru Yang and Wen Zhou \\ Yunnan College of Foreign Affairs \& Foreign Language Yang Lin 651700
}

Keywords: Talent training; Evaluation criteria; Results

\begin{abstract}
With the progress of society and the times, the society has become more and more demanding for innovative and entrepreneurial talents. The traditional way of cultivating innovative and entrepreneurial talents has been unable to meet the needs of social development. In recent years, the school-enterprise cooperation innovation and entrepreneurial talent training model has gradually been taken seriously by universities, enterprises, and even the society. The mode of school-enterprise cooperation fully plays the advantages of schools and enterprises to cultivate the creative talents who meet the requirements of social development. Therefore, this paper explores the evaluation system of the quality of innovation and entrepreneurship training in colleges and universities under the collaborative model, which is of great significance for advancing the quality of personnel training in universities in China. The standard of university talents is to assess the innovation and entrepreneurial talents of today's college students, and to develop more innovative entrepreneurial talents from the framework of colleges and universities' innovation and entrepreneurship education. Hope to help colleges and universities in innovation and entrepreneurship education.
\end{abstract}

\section{Introduction}

The ability of college students in our country to adapt to society, employment and entrepreneurship is not strong, and innovative, practical and compound talents are in short supply. For a long time, although various levels of departments have implemented various preferential policies and measures to actively promote innovation and entrepreneurship education for college students, and all kinds of colleges and universities have actively cultivated innovative and talented personnel training models to create innovative entrepreneurial talents, it can be said that the cultivation of China's innovation and entrepreneurship talents is still in the early stages of development. Many issues concerning the cultivation of innovative entrepreneurial talents need to be explored theoretically and practically. In the innovation and entrepreneurship training mode, how to evaluate and select innovative and entrepreneurial talents is the most crucial issue. Therefore, it is very important to build a talent evaluation system for innovation and entrepreneurship. Combining the actual needs of talented people in the society, the evaluation of innovative talents mainly consists of three indicators: knowledge level, mental quality, and ability structure. The knowledge level includes professional basic knowledge, professional related knowledge, and innovation and entrepreneurial professional knowledge; the mental quality includes physical quality, moral character, cultural quality, and psychological personality quality; the ability structure includes insight, decision-making power, execution power, learning ability, leadership and anti-risk ability.

\section{Evaluation Criteria for Innovative and Entrepreneurial Talents}

\section{Knowledge level}

The personal knowledge of a university through systematic training is a sufficient condition for innovation and entrepreneurship, but it is not a necessary condition. The more personal knowledge, the wider knowledge, and the more reasonable the knowledge structure, the greater the creativity. For the knowledge level of innovation and entrepreneurship, we should include three indicators.

(1) Must have the basic knowledge required in the professional training plan. This kind of knowledge is different from the requirements of different professional fields, such as the knowledge 
of international economy and trade related to the international economy and trade major, such as the theory economics, the applied economics and so on.

(2) Knowledge related to the major of the study. For international trade professionals, it is necessary to know and understand the laws and regulations of the internal and external environment of the market, society and enterprises, especially the company law, the tax law, the international commercial law, and the related products such as physical and chemical knowledge, such as the products that may be encountered in the international trade.

(3) How to implement the basic knowledge of innovation and entrepreneurship. That is, we must learn how to implement entrepreneurial management and how to create relevant knowledge such as enterprises.

2. Mental quality

Mental quality is an auxiliary condition that the individual must have in the process of innovation and entrepreneurship. If it lacks these qualities, even with the strong ability, it can not achieve success. Mainly through physical quality, moral character, cultural quality, psychological personality quality four indicators to assess.

(1) Physical quality. Including two aspects of personal physical health and mental health, good physical fitness is the foundation of entrepreneurship, without healthy body and energetic strength and energy, the rich knowledge and entrepreneurial opportunities are difficult to put into practice, or at least affect the normal development of innovative and entrepreneurial ability.

(2) Moral quality. It includes personal moral character, political accomplishment, legal consciousness, integrity consciousness, cooperation consciousness and so on. The modern society needs talents with both moral integrity and ability. In addition to the professional skills and talents to create wealth, it is necessary to have a sense of mission, social responsibility, sense of crisis, sense of justice and good cooperation consciousness as a founder and manager of an enterprise.

(3) Cultural quality. Cultural quality refers to the more stable and intrinsic quality that people have in culture, which shows the quality, level and personality of people in these knowledge and the ability to adapt to it, emotion and so on. It mainly examines the basic cultural accomplishment and cultural concept of the talents.

(4) Psychological personality quality. Personal psychological personality generally includes human psychological process, cognitive ability, behavior motivation, emotional reaction, interpersonal relationship, attitude belief, moral value, aesthetic interest and so on. The external embodiment of these characteristics in dealing with all kinds of problems is manifested as psychological personality quality.

\section{Capacity structure}

Compared with the general graduates, the creative and entrepreneurial talents should have a better ability structure, so it should be given higher evaluation standards and requirements from the ability structure. Mainly from the following aspects to be inspected.

(1) Insight. Insight is a thorough analysis of people's motives and relationships of personal cognition, emotion and behavior, and sharp insight plays an important role in seeking innovative behaviors such as business opportunities and scientific discoveries. This ability of innovation and entrepreneurship talents cannot be formed by relying on the knowledge of books. It is an inherent instinct that needs to be tempered by long-term business practices and can only be formed over time.

(2) Decision-making power. Decision-making ability is the core part of management ability. Practice has proved that the size of entrepreneur's decision-making power will be influenced by many factors, such as decision-making space, decision-making efficiency, decision idea and so on. The size of the decision space determines the openness of the entrepreneur's vision and the openness of the thinking. If the decision-making space is small and the thinking is restricted by all aspects, it is impossible to make a high quality decision.

(3) Execution. This ability examines the innovative and entrepreneurial talents to carry out the strategic intention of the enterprise and complete the operational ability of the intended target, which is the key to transforming the enterprise strategy and planning into benefits and results. For 
innovative entrepreneurs, their execution requires not only the willingness to complete the task, but also the timely and quantitative completion of their work tasks, and the ability to complete the task creatively.

(4) Learning ability. Learning ability refers to the sum of one's learning motivation, learning perseverance and learning ability. It shows the ability of people to acquire knowledge, share knowledge, use knowledge, create knowledge, promote themselves and promote social development and progress. It can dynamically measure the comprehensive quality of innovative and entrepreneurial talents and the strength of their competitiveness.

\section{Building Up a Training System for Innovative and Entrepreneurial Talents}

Colleges and universities always adheres to the idea of educating people, establishing a quality school, strengthening schools with talents, starting schools with scientific research, and highlighting the characteristics of running a school. It clearly puts forward the talent training objectives of "one broad, three strong and all-round development" to cultivate a wide range of knowledge, strong practical abilities, strong adaptability, a strong sense of innovation and entrepreneurship, and a comprehensive development of morality, intelligence, and physical beauty. With the aim of cultivating talents, the school is to promote the overall development of college students, to promote the awareness, spirit and ability of college students to be the core, to strengthen the system construction, to improve the guarantee system, and to form an innovative and entrepreneurial education management mechanism for college students, such as educational affairs, scientific research and employment.

1. Reform the mode of personnel training and highlight innovation and entrepreneurship education.

Innovation and entrepreneurship education should be aimed at all students and integrate into the whole process of personnel training. The training process is divided into basic and professional "two stages" "three specifications" (major, minor, double degree), "three platforms" (quality education platform, professional education platform, practical teaching and personalized education platform), "three levels" (public courses, subject common courses, professional courses), Highlight the "four emphasize and one specialize",means emphasizing the foundation, emphasizing practice, emphasizing innovation and entrepreneurship, and emphasizing individualized training, strive to "general and specialized combination". Bringing innovation and entrepreneurship education into credit management system and implementing individualized education. In different stages, different teaching links, targeted innovation and entrepreneurship activities.

2. Optimize the course system construction and scientifically set up the curriculum structure.

Classroom teaching is the foundation of innovation and entrepreneurship education. In order to optimize the curriculum system, the school will increase the time and space of students' self-study, promote the development of individuality, strengthen the integration and reorganization of the curriculum, realize the interdisciplinary and integration of the subjects, strengthen the strength of the cultivation of the students' humanistic quality, and emphasize the organic combination of learning and research, learning, practice and research. In the construction of the "three platform" course system, a new curriculum system is constructed with platform structure, module structure and the combination of platform and module.

3. Strengthen practice teaching and pay attention to the cultivation of practical ability.

Practice teaching and individualized education platform are the bridge between theory and practice, and also an important link to cultivate students' ability of innovation and entrepreneurship. According to the specialty characteristics of the subject, the practice teaching system is constructed. In the talent training program, the basic framework of "basic requirements and individualization training" is taken as the basic framework. According to the three levels of basic practice, professional practice and comprehensive practice, the practical teaching link and its operating system are arranged scientifically, and the running period of each practice teaching link is arranged in a standardized and orderly manner. 


\section{Increased Awareness, Improved Ability, and Remarkable Achievements in Innovation and Entrepreneurship Training}

Always adhere to full education, whole process education, all-round education, and individualized training. Through the construction and implementation of innovation and entrepreneurship training system for undergraduates, the concept of employment and career choice of students has been gradually transformed, the awareness of innovation and entrepreneurship has been stimulated, the spirit of innovation and entrepreneurship has been further explored, and the ability of innovation and entrepreneurship has been significantly improved.

1. Aroused awareness of innovation and entrepreneurship

Schools use classroom teaching as the main channel, through series of lectures, forums and employment and other activities to effectively stimulate college students' awareness of innovation and entrepreneurship. In the innovative and entrepreneurial classroom, the teaching methods are constantly improved, focusing on students as the center, integrating scene simulation, grouping discussion and sharing, business games, entrepreneur interviews, group tasks, case discussion, brainstorming and many other forms, to encourage students to take the initiative and experience their own experience, that reflect more participation characteristics. Every year, the school invites employers to hold a recruitment meeting on campus to build a platform for graduates to communicate with employers, so that students can understand the social needs and gradually establish a scientific concept of career selection and employment.

2. Further pioneering spirit of innovation and entrepreneurship

The spirit of innovation and entrepreneurship is not only an inexhaustible motive force for the development of a country and a nation, but also a quality that a contemporary university student should possess. By combining the first class with the second class organically, the school carries out the activities of innovation and entrepreneurship, competition, the construction of student associations and social practice, and trains the students' ideas of innovation and entrepreneurship, strengthens the sense of social responsibility and the noble moral sentiment of serving the masses, and promotes the further development of the innovation and entrepreneurial spirit.

3. The ability of innovation and entrepreneurship is improved

Through practice and exploration, starting from the training scheme, focusing on the cultivation of innovative and entrepreneurial talents, constantly improving the curriculum system, practical teaching system, management system, security system, incentive measures, and gradually built a "student-centered approach to improve the awareness of innovation and entrepreneurship, the spirit of innovation and entrepreneurship and the ability of employment and entrepreneurship of students as the goal, with the idea of innovation, thinking innovation, institutional innovation, method innovation as the focus, and innovation and entrepreneurship education throughout the entire process of university education" college students innovation and entrepreneurship training system. And has obtained the outstanding achievement in the practice application, a batch of high-quality applied and compound talents with solid foundation, broad knowledge, strong adaptability, full development of morality, intelligence, and beauty are trained to meet the needs of economic construction and social development in the national and frontier ethnic areas.

\section{Summary}

Innovation and entrepreneurship education is no longer a requirement for the realization of a few students' self actualization, but should be standardized and institutionalized in higher education. Innovation and entrepreneurship education has become an inevitable trend of higher education. However, there are still many defects in the cultivation of talents in China's innovation and entrepreneurship education. In the process of cultivating innovative and entrepreneurial talents, it is necessary to grasp what kind of talents can be called innovative and entrepreneurial talent, which requires a standard of evaluation. Therefore, the evaluation of innovative entrepreneurial talents is particularly important. Through the analysis of the evaluation standards of innovative entrepreneurial talent, and then the establishment of the index system, the evaluation method is used 
to evaluate the innovative and entrepreneurial talents, and the training methods of innovation and entrepreneurship education are pointed out, and then the direction of innovation and entrepreneurship education is pointed out.

\section{Acknowledgement}

Fund projects: The Yunnan Provincial Department of Education (2018JS877)

Topic name: Research on training path and evaluation system of Applied Innovative Talents in Higher Vocational Colleges

\section{References}

[1] Mcphee C. Editorial: Innovation and Entrepreneurship (December 2014)[J]. Technology Innovation Management Review, 2014, 4(12).

[2] Edwards M, Sanchezruiz L M, Tovarcaro E, et al. Engineering students' perceptions of innovation and entrepreneurship competences[C]// Frontiers in Education Conference, 2009. Fie '09. IEEE. IEEE, 2009:1-5.

[3] Yan-Bo L I, Liu S X. A Mode of Innovation and Entrepreneurship Education Based on a Plan for Educatingand Training Outstanding Application Talents[J]. Journal of Higher Education Finance, 2013.

[4] Carayannis E G, Samara E T, Bakouros Y L. Innovation and entrepreneurship : theory, policy and practice[M]. Springer, 2014.

[5] Xiao-Hua L I, Zhang L P, Wang X F. A Research on Innovation and Entrepreneurship Education System Construction of Local Colleges and Universities[J]. Journal of Hebei University of Science \& Technology, 2015.

[6] Feng A N, Jin Y. Teaching practice of innovation and entrepreneurship for"Modem Business Management"course base on ERP training[J]. Journal of University of Science \& Technology Liaoning, 2014.

[7] Sheng Y, Yu Q, Chen L. A Study on the Process Oriented Evaluation System of Undergraduate Training Programs for Innovation and Entrepreneurship[J]. Creative Education, 2016, 07(15):2330-2337.

[8] Ezenwakwelu C A, Ikon M A. Empirical Analysis on Innovation and Implication for Entrepreneurship Development in Nigeria[J]. European Journal of Business \& Management, 2014.

[9] Hong J I, Fei Z Y, Zhang G H, et al. Practice and Reflection of Innovation and Entrepreneurship Education in Local Applied Universities[J]. Research \& Exploration in Laboratory, 2016.

[10] Gündoğdu M Ç. Re-Thinking Entrepreneurship, Intrapreneurship, and Innovation: A Multi-Concept Perspective[J]. Procedia - Social and Behavioral Sciences, 2012, 41:296-303.

[11] Research on promoting achievement transformation of Undergraduate Training Programs for Innovation and Entrepreneurship[J]. Pioneering with Science \& Technology Monthly, 2016.

[12] Gay B. Open innovation, networking, and business model dynamics: the two sides[J]. Journal of Innovation \& Entrepreneurship, 2014, 3(1):1-20.

[13] Modrego F, Mccann P, Foster W E, et al. Regional entrepreneurship and innovation in Chile: a knowledge matching approach[J]. Small Business Economics, 2015, 44(3):685-703.

[14] Zhang D W, Wang C, University H E. Research on Innovation and Entrepreneurship Education and New Talent Training[J]. Education Teaching Forum, 2018.

The author introduces: Boru Yang (1989.6-), female, Hebei Tangshan, lecturer title, research direction: human resources management; Wen Zhou(1974.6-), male,, Chongqing, lecturer title, research direction: organizational behavior management 